\title{
BUSINESS
}

\section{Carbon market survives gas leaks}

\section{Searing volatility has led some to dismiss Europe's nascent emissions market as a farce - but it is still hanging in there. Quirin Schiermeier reports on the project's teething troubles.}

$\bigcirc$ $\mathrm{n}$ the closing Friday of Carbon Expo in Cologne earlier this month, a crowd of nervous emissions traders was seen swarming around the stand of a German consultancy firm.

The focus of their attention was an analyst who had managed to log on to a supposedly secure European Commission website. The site listed verified data on carbon dioxide emissions from thousands of large companies. The commission was due to release these marketsensitive data the following Monday, 15 May.

As reports spread that power producers and other energy-intensive European industries were sitting on unused allowances for $60 \mathrm{mil}$ lion tonnes of carbon dioxide emissions, the price of the permits that allow for extra emissions dropped by nearly a third. Traders' reactions to the leaking of the data varied from "unbelievable" to "a complete farce". Only the arrival of the weekend, they said, saved the market from a complete meltdown.

When the commission officially announced on 15 May that large industrial firms in the European Union (EU) were in fact just $44 \mathrm{mil}$ lion tonnes under the permitted limit for 2005, the market decided that the crisis wasn't quite so bad. It settled somewhat, at about half its April peak.

The commission later apologized for the "technical error". But the incident summed up the immaturity of the EU Emissions Trading Scheme (ETS), a cap-and-trade system introduced in January 2005 with the goal of cutting greenhouse gases. The world looks to the ETS as a possible model for a global trading system, and is watching its progress with interest.

\section{Accidentalemissions}

The leak wasn't the first of its kind: late last month, prices of emission allowances crashed from $€ 31$ (US $\$ 40$ ) to around $€ 12$, following leaks of emissions data for France, the Netherlands, Sweden, Spain, Belgium and the Czech Republic. Most of these countries reported significantly lower emissions than had been foreseen by their respective national plans.

Not all countries have come in below target: British companies emitted 33 million tonnes more carbon dioxide than they were allowed. The excess will put particular pressure on emitters in export-dependent sectors such as the steel industry, which cannot readily hand on the

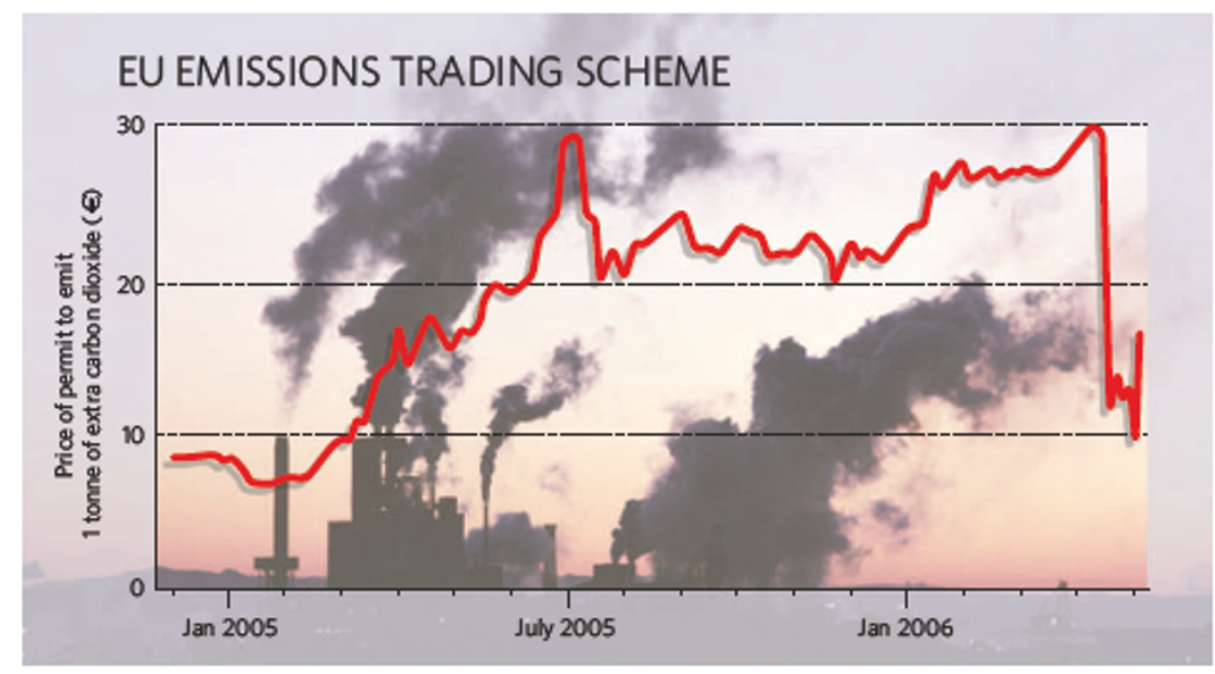

cost of buying permits to their customers. The largest emitters - electricity generators probably will hand on such costs, but they're not happy about it: five British firms are suing the European Commission, claiming that the UKallocation is too small.

Across the EU, however, over-allocation of emissions rights in the first trading period seems to be the biggest threat to the ETS.

"If the price of carbon is too low, it will hinder investment in cleaner technologies," says Martina Priebe, who watches the ETS for the International Emissions Trading Association in Geneva, Switzerland. "In the worst case the whole cap-and-trade exercise will have no effect at all on investment decisions."

For the system to work properly, the total number of allowances allocated to industry needs to be smaller than the actual emissions, agrees Barbara Helfferich, a spokeswoman for the European Commission. But she says it was difficult to estimate the right baseline because data on past emissions levels didn't exist. Instead, the commission
"The only thing the trading scheme has not yet done is reduce emissions." will be adjusted accordingly, says Helfferich.

${ }^{\alpha}$ The commission acted on the cautious side," says Guy Turner, director of Londonbased New Carbon Finance. ${ }^{\alpha}$ This is understandable because they knew that excessively high prices would have been disastrous."

Volatility may be a problem for investors but it is typical for young environmental commodity markets, such as the one that successfully controls sulphur dioxide emissions in the United States. And although the ETS market may have fallen, it is still functioning.

"Emissions trading works," says Peter Kreuzberg, head of trading at the German energy company RWE. He notes that high market volume and liquidity have been achieved quickly. But he adds that the ETS reporting system needs to be strengthened and its allocation process made more transparent. These flaws must be addressed if the scheme is to help the EU meet its target of reducing industrial carbon dioxide emissions to $6 \%$ below current levels before 2010. ${ }^{\alpha}$ The performance of the ETS stacks up well against most criteria," says used data on past energy consumption and projected economic growth rates to estimate allowances for the 11,500 installations covered by the ETS.

The $25 \mathrm{EU}$ member states must submit their national allocations for the second trading period, 2008-12, by the end of June. These can now take into account verified data and
Turner. ${ }^{\alpha}$ The only thing it has not yet done is reduce emissions."

${ }^{\alpha}$ The system is not a failure despite what has happened in the past few weeks," says Priebe. The commission can't control the market's value - but, she says, it needs to do far more to control the quality of data that underpin it. 